\title{
VARIATION OF CHEMICAL AND MORPHOLOGICAL CHARACTERS OF LEAVES AND UNRIPE CONES IN JUNIPERUS COMMUNIS
}

\author{
Vaida VAIČIUlYTĖ, Kristina LožIENË*
}

Nature Research Centre, Institute of Botany, Žaliųų Ežerų Str. 49, LT-08406 Vilnius, Lithuania;

*Corresponding author. E-mail: kristina.loziene@gmail.com

\begin{abstract}
Vaičiulytė V., Ložienė K., 2013: Variation of chemical and morphological characters of leaves and unripe cones in Juniperus communis [Paprastojo kadagio (Juniperus communis) lapų bei neprinokusių kankorėžèlių cheminių ir morfologinių parametrų ịvairavimas]. - Bot. Lith., 19(1): 37-47.

The variation of content of essential oil and pinene isomers and morphological parameters of leaves and unripe cones in Juniperus communis L. was studied. Leaves and cones were collected separate from $110 \mathrm{~J}$. communis individuals in 11 different habitats throughout Lithuania. Essential oils were analysed by capillary gas chromatography (GC). The study showed more intensive essential oil accumulation and higher intraspecific variation of essential oil amount in unripe cones than in leaves. Significant differences between $\alpha$ - and $\beta$ - pinene amounts were observed in $J$. communis. $\beta$-Pinene was detected in much higher quantities than $\alpha$-pinene. Positive correlation was detected between pinene isomers in cones and leaves $(r=0.44, p<0.05$ and $r=0.50, p<0.05$, respectively) of the same tree showing pinene isomers common biosynthetic pathway. Significant differences between populations were characteristic of J. communis according to leaf length, unripe cones mass and essential oil yield in leaves, however, significant correlation was established between essential oil yield of leaves and habitat illumination $(\mathrm{r}=-0.67, \mathrm{p}<0.05)$ and soil acidity $(\mathrm{r}=-0.80, \mathrm{p}<0.05)$ only.
\end{abstract}

Keywords: Juniperus communis, leaves, unripe cones, essential oils, pinene isomers, morphological and chemical variation, abiotic factors.

\section{INTRODUCTION}

Juniperus communis L. (Cupressaceae Rich. ex Bartl.) is a volatile secondary metabolites essential oils bearing and wide spreading conifer in the world (ADAms, 2004; Rook, 2006). The quantitative and qualitative composition of essential oils extracted from cones (ripe and unripe), leaves, wood and roots varies both between individual plants and between plant parts in this species (BERTA, 1993; BUTKIENE et al., 2006; GonNy et al., 2006; MARONGIU et al., 2006). The highest amounts of essential oil were established in unripe cones (twice more than in ripe cones), the lowest - in wood and roots. Commonly predominant essential oil compound in all parts of $J$. communis is monoterpene $\alpha$-pinene, the contents of which can reach up to $80.4 \%$ (ANGioni et al., 2003; Shahmir et al., 2003; ButKIENĖ et al., 2006, ButKIENĖ et al., 2009; Filipowicz et al., 2009). $\alpha$-Pinene is considered as biologically active compound, determining the main pharmacological properties of $J$. communis (CAVALEIRO et al., 2006; LEITE et al., 2007). The literature suggests that another pinene isomer $\beta$-pinene is characteristic of wider spectrum of antibacterial activity than $\alpha$-pinene (Dorman \& DeAns, 2000). Isomer $\beta$-pinene is sometimes found in the essential oils of $J$. communis, however, in lower amounts (LožIENĖ et al., 2010).

The high ecological amplitude is typical of $J u$ niperus communis: it is frequent in dry pinewoods, on river valleys, however, occurs on wet soils, too (GARCIA et al., 2000; Thomas et al., 2007); it is light- 
demanding and intolerant of deep shade $(<1.6 \%$ daylight), but can grow in little as $20.5 \%$ daylight (GrubB et al., 1996; Humphrey, 1996). Such ecological amplitude of $J$. communis can be one of the reasons for morphological variation as well as quantitative and qualitative diversity of essential oils (Adams, 1998; Chatzopoulou \& Katsiotis, 2003; Cavaleiro et al., 2003). Cones and its essential oils are pharmaceutical raw material (CouNCIL OF EUROPE, 2008). Leaves accumulate lower amounts of essential oil, therefore, form a big part of plant biomass, which evaporate volatile compounds to atmosphere.

The purpose of this study was to quantify the variation of Juniperus communis cones and leaves by some morphological and chemical (amount of essential oils and pinene isomers) characters in relation to different ecological conditions of habitats in Lithuania.

\section{MATERIALS AND METHODS}

Plant material. First-year (unripe) cones and current-year shoots of Juniperus communis were sampled from 11 natural habitats, which differed by illumination intensity (open or shaded habitats) and soil characteristics, such as soil acidity, contents of organic nitrogen, mobile phosphorus, mobile potassium and humus in Lithuania in August 2010 (Table 1). Distances between habitats were no less than $10 \mathrm{~km}$ (Fig. 1). Ten female individuals being of normal development, similar in height and stem diameter were selected in each habitat randomly. In order to avoid any effect of dioeciousness, which is typical of this species (ADAMs, 2004), only female individuals were used for leaves and unripe cones sampling. Plant material was collected separately from each of the individuals and dried at room temperature.

Table 1. Characteristics of studied habitats of Juniperus communis (habitat numbers in Table 1 are in character with habitat numbers in Fig.1)

\begin{tabular}{|c|c|c|c|c|c|c|c|c|}
\hline No. & $\begin{array}{l}\text { Habitat locality } \\
\text { (municipality) } \\
\text { coordinates WGS-84 }\end{array}$ & $\begin{array}{l}\text { Short ecological } \\
\text { characteristics }\end{array}$ & $\mathrm{pH}_{\mathrm{KCL}}$ & $\mathrm{N}_{2}(\%)$ & $\begin{array}{c}\mathrm{P}_{2} \mathrm{O}_{5} \\
(\mathrm{mg} / \mathrm{kg})\end{array}$ & $\begin{array}{c}\mathrm{K}_{2} \mathrm{O} \\
(\mathrm{mg} / \mathrm{kg})\end{array}$ & Humus & $\begin{array}{l}\text { Lighting } \\
\text { (klux) }\end{array}$ \\
\hline \multicolumn{9}{|c|}{ Open habitats } \\
\hline 1 & \begin{tabular}{|l} 
Arlaviškės (Kaunas) \\
$54.812828,24.181667$ \\
\end{tabular} & \begin{tabular}{|l|} 
Dry meadow, slope, \\
inclination $40^{\circ}$, aspect $\mathrm{S}$
\end{tabular} & $6.5 \pm 0.6$ & $0.20 \pm 0.03$ & $67 \pm 23$ & $156 \pm 21$ & $3.6 \pm 0.4$ & 35.0 \\
\hline 2 & $\begin{array}{l}\text { Sekionys (Kaišiadorys) } \\
54.688837,24.097153\end{array}$ & $\begin{array}{l}\text { Dry meadow, slope, } \\
\text { inclination } 40^{\circ} \text {, aspect } \\
\text { S-SW }\end{array}$ & $7.3 \pm 0.1$ & $0.33 \pm 0.06$ & $153 \pm 35$ & $311 \pm 72$ & $4.9 \pm 0.3$ & 31.0 \\
\hline 3 & \begin{tabular}{|l} 
Savaitiškès (Trakai) \\
$54.500552,24.707439$
\end{tabular} & $\begin{array}{l}\text { Dry meadow, slope, } \\
\text { inclination } 35^{\circ} \text {, aspect E7 }\end{array}$ & $5.1 \pm 0.4$ & $0.31 \pm 0.08$ & $180 \pm 72$ & $194 \pm 106$ & $4.9 \pm 1.5$ & 28.0 \\
\hline 4 & \begin{tabular}{|l} 
Šaukliai (Skuodas) \\
$56.127208,21.591581$ \\
\end{tabular} & $\begin{array}{l}\text { Dry meadow, moraine, } \\
\text { plain }\end{array}$ & $5.1 \pm 0.9$ & $0.25 \pm 0.11$ & $54 \pm 41$ & $78 \pm 18$ & $5.1 \pm 1.8$ & 30.0 \\
\hline 5 & $\begin{array}{l}\text { Bradesiai (Zarasai) } \\
55.838684,25.848121\end{array}$ & $\begin{array}{l}\text { Dry meadow, slope, } \\
\text { inclination } 40^{\circ} \text {, aspect } \\
\text { S-SW }\end{array}$ & $6.7 \pm 0.3$ & $0.18 \pm 0.03$ & $86 \pm 26$ & $131 \pm 10$ & $3.3 \pm 0.2$ & 30.0 \\
\hline $6^{*}$ & \begin{tabular}{|l|} 
Šminai (Ignalina) \\
$55.3995,26.0559$
\end{tabular} & Calcareous fen, plain & $7.7 \pm 0.1$ & $1.01 \pm 0.30$ & $75 \pm 14$ & $71 \pm 13$ & $\begin{array}{l}14.4 \pm \\
4.6\end{array}$ & 29.0 \\
\hline \multicolumn{9}{|c|}{ Shaded habitats } \\
\hline 7 & $\begin{array}{l}\text { Tetervinai (Šalčininkai) } \\
54.318833,25.040402 \\
\end{array}$ & $\begin{array}{l}\text { Coniferous wood, river- } \\
\text { side, undulated plain }\end{array}$ & $4.3 \pm 0.1$ & $0.05 \pm 0.00$ & $88 \pm 16$ & $16 \pm 3$ & $1.7 \pm 0.2$ & 12.0 \\
\hline 8 & $\begin{array}{l}\text { Degsnės (Varėna) } \\
54.381604,24.7848\end{array}$ & Coniferous wood, plain & $4.2 \pm 0.0$ & $0.13 \pm 0.03$ & $149 \pm 51$ & $25 \pm 6$ & $3.7 \pm 0.5$ & 11.5 \\
\hline 9 & \begin{tabular}{|l} 
Rudnia (Šalčininkai) \\
$54.199572,25.706204$ \\
\end{tabular} & Coniferous wood, plain & $5.6 \pm 0.2$ & $0.04 \pm 0.01$ & $103 \pm 7$ & $24 \pm 1$ & $1.4 \pm 0.2$ & 5.0 \\
\hline 10 & \begin{tabular}{|l|} 
Peleniai (Kelme்) \\
$55.844219,22.897986$ \\
\end{tabular} & Coniferous wood, plain & $4.1 \pm 0.2$ & $0.07 \pm 0.02$ & $115 \pm 6$ & $28 \pm 10$ & $2.1 \pm 0.9$ & 13.0 \\
\hline 11 & \begin{tabular}{|l|} 
Ginučiai (Ignalina) \\
$55.392444,25.994218$ \\
\end{tabular} & $\begin{array}{l}\text { Coniferous wood, } \\
\text { undulated relief }\end{array}$ & $4.8 \pm 0.6$ & $0.04 \pm 0.02$ & $88 \pm 16$ & $24 \pm 4$ & $1.9 \pm 0.4$ & 9.0 \\
\hline
\end{tabular}

* - control habitat No. 6 was not included in the statistical analyses of this paper. 


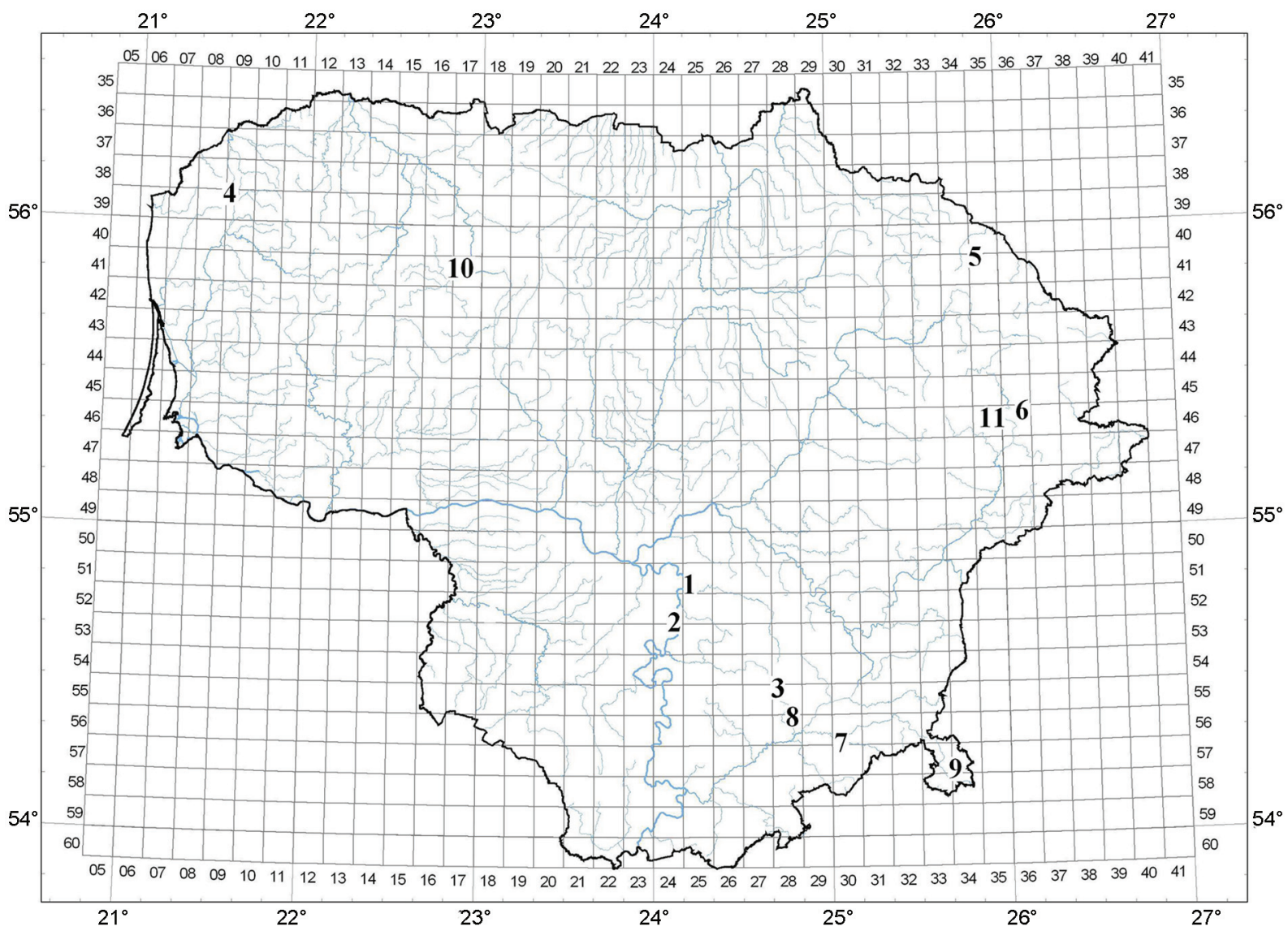

Fig. 1. Locations of the studied Juniperus communis habitats in Lithuania

Habitat evaluation. Illumination was measured in kiloluxes with photoradiometer HD 2302.0 in three places per habitat at around the midday time and a clear sky condition. Soil samples were taken from the depth of $10-15 \mathrm{~cm}$ at three randomly chosen, remote from each other places per habitat. The contents of organic nitrogen $\left(\mathrm{N}_{2}\right)$, mobile phosphorus $\left(\mathrm{P}_{2} \mathrm{O}_{5}\right)$ and humus in soil were estimated photoelectrocolorimetrically, and mobile potassium $\left(\mathrm{K}_{2} \mathrm{O}\right)$ - by flame photometry. Soil acidity $(\mathrm{pH})$ was estimated electrometrically using $1 \mathrm{M} \mathrm{KCl}$ solution.

Morphological analysis. The mass of 100 leaves, the mass of 100 unripe cones and the lengths of leaves were assessed in 110 plants (in ten plants from each habitat). Three hundred randomly selected leaves per sample were used for length measurements. In three weighing per individual plant were used for the measurement of the mass of leaves and unripe cones.

Essential oil isolation and quantitative analysis. Essential oils were isolated from 110 samples of leaves and 110 samples of unripe cones by hydrodistillation in Clevenger-type apparatus (Simax) during two hours (Council of Europe, 2008). The contents of essential oils were evaluated by percent (\%) in air-dry weight.

Analysis of pinene isomers using GC-FID. Essential oils solutions of $1 \%$ were prepared in mixture of diethyl ether and n-pentane (1:1) for further investigations. The analysis of monoterpene pinene isomers was carried out using a FOCUS GC (Thermo Scientific) gas chromatograph with a flame ionisation detector (FID). Data were processed with the CHROM-CARD S/W.

The silica capillary column TR-5 (30 m, i. d. 0.25 $\mathrm{mm}$, film thickness $0.25 \mu \mathrm{m}$ ) was used for the analysis of the $\alpha$ - and $\beta$-pinene with the following GC parameters: carrier gas helium flow rate $1.6 \mathrm{ml} / \mathrm{min}$; temperature programme from $40^{\circ} \mathrm{C}$ to $250^{\circ} \mathrm{C}$ increasing at $4^{\circ} \mathrm{C} / \mathrm{min}$; detector temperature $260^{\circ} \mathrm{C}$; split injector was heated at $250^{\circ} \mathrm{C}$. The identification of $\alpha$ - and $\beta$-pinene was carried out by the comparison of the retention time (RT) of their GC peaks in the FID chromatograms with the RT of $\alpha$ - and $\beta$-pinene ana- 
lytical standards (Sigma-Aldrich) (Fig. 2). The percentage amounts of pinene isomers were recalculated according to the areas of the FID chromatographic peaks assuming that all constituents of the essential oil comprise $100 \%$.

Statistical analysis. The statistical analyses were carried out only in 10 habitats: habitat No. 6 was not included in the statistical analyses, because it distinguished by some ecological characters (was calcareous fen and had signally higher contents of humus and organic nitrogen in soil) from other habitats (Table 1). The normality of the data distribution was tested by the Shapiro-Wilk test. The Pearson correlation coefficient was used to test whether the investigated morphological and chemical parameters of Juniperus communis are interdependent and how they correlate with the parameters (soil characteristics, lighting) of the habitats. The one-way analysis of variance (ANOVA) and the $t$-test were used to test the differences in the investigated morphological and chemical parameters of $J$. communis at betweenpopulation level. Statistical analyses were conducted using STATISTICA ${ }^{\circledR} 7$ and MS Excel software.

\section{RESULTS}

After the study of 100 cone-bearing juniper trees, the following averages of leaf length, mass of 100 leaves and mass of 100 unripe cones were estimated: $12.3 \pm 1.55$ (SD) mm, $0.163 \pm 0.029$ (SD) $g$ and $2.928 \pm 0.877$ (SD) g, respectively. Leaf length and leaf mass varied similarly at individual plant level: min-max values of leaf length $(9.0-16.4 \mathrm{~mm})$ and leaf mass $(0.114-0.291 \mathrm{~g})$ differed twice; variation coefficients were similar $(13 \%$ and $18 \%$, respectively). The variation of cones mass was higher - from 1.461 to $5.617 \mathrm{~g}(\mathrm{~V}=30 \%)$. Also statistically significant positive correlation was observed between leaf length and leaf mass $(r=0.44, p<0.05)$ (Fig. 3).

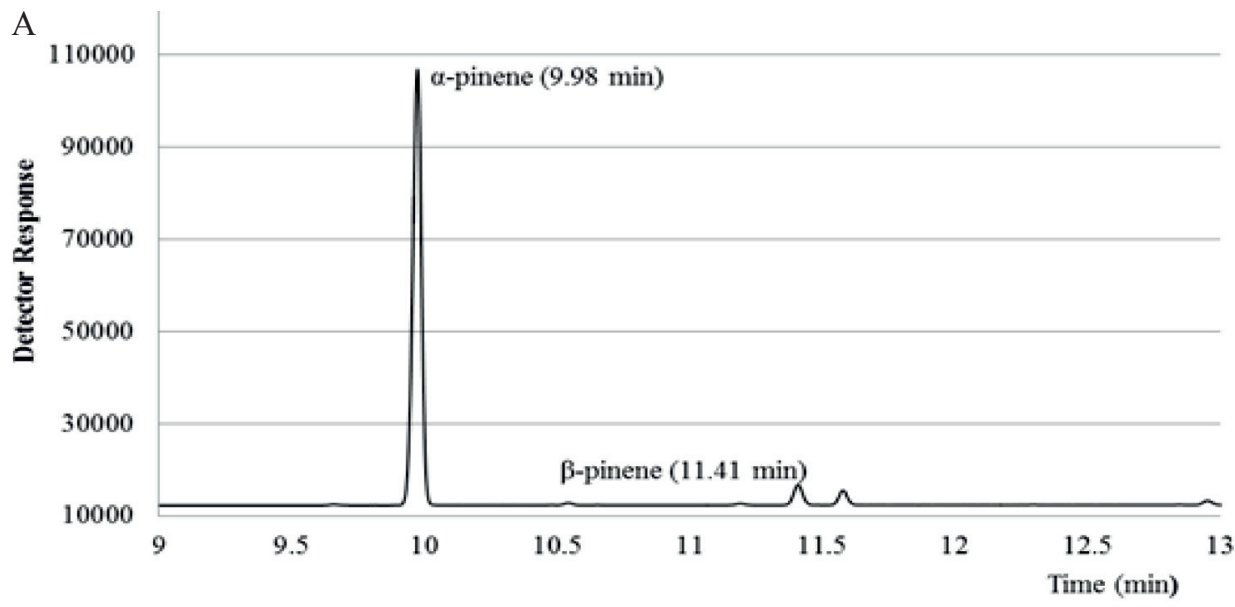

B

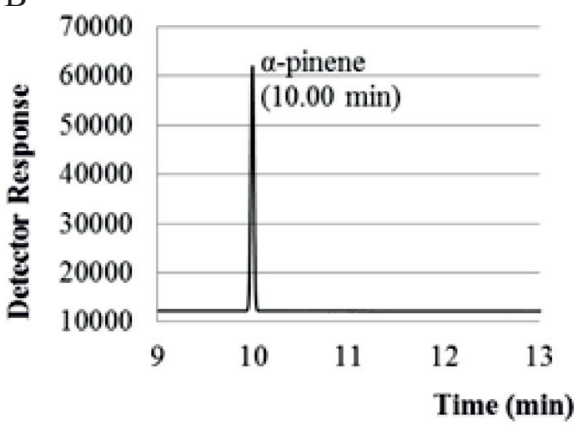

C

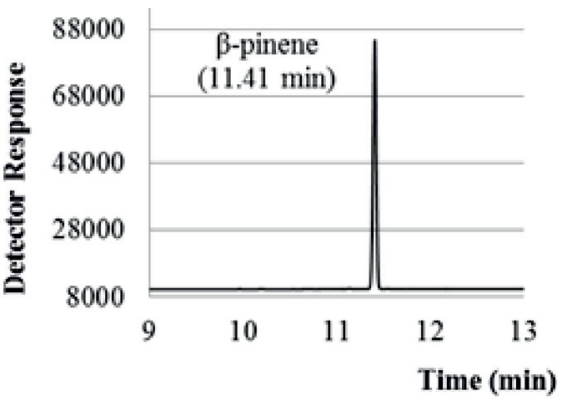

Fig. 2. Capillary GC analysis of pinene isomers in the studied Juniperus communis (A) in comparison with its analytical standards $(\mathrm{B}, \mathrm{C})$ 
A $\alpha$-Pinene in leaves $=23.044+15.931 \times \beta$-pinene in leaves

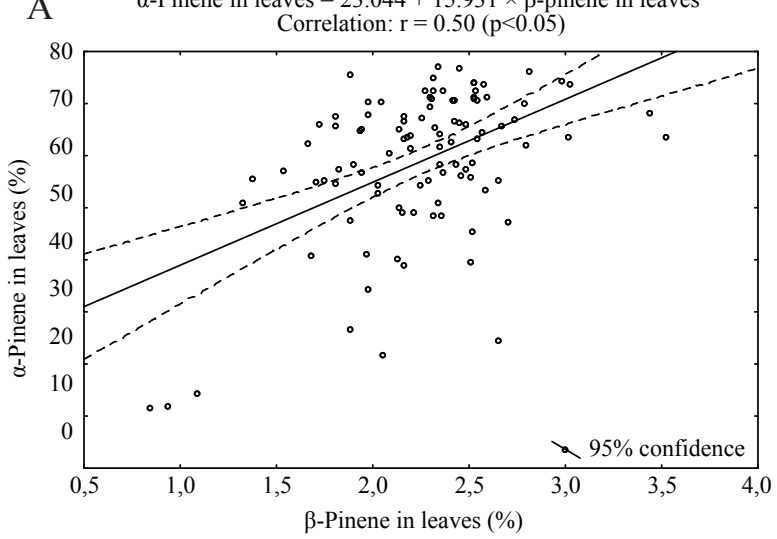

B $\alpha$-Pinene in unripe cones $=38.275+9.224 \times \beta$-pinene in unripe cones Correlation: $\mathrm{r}=0.44(\mathrm{p}<0.05)$
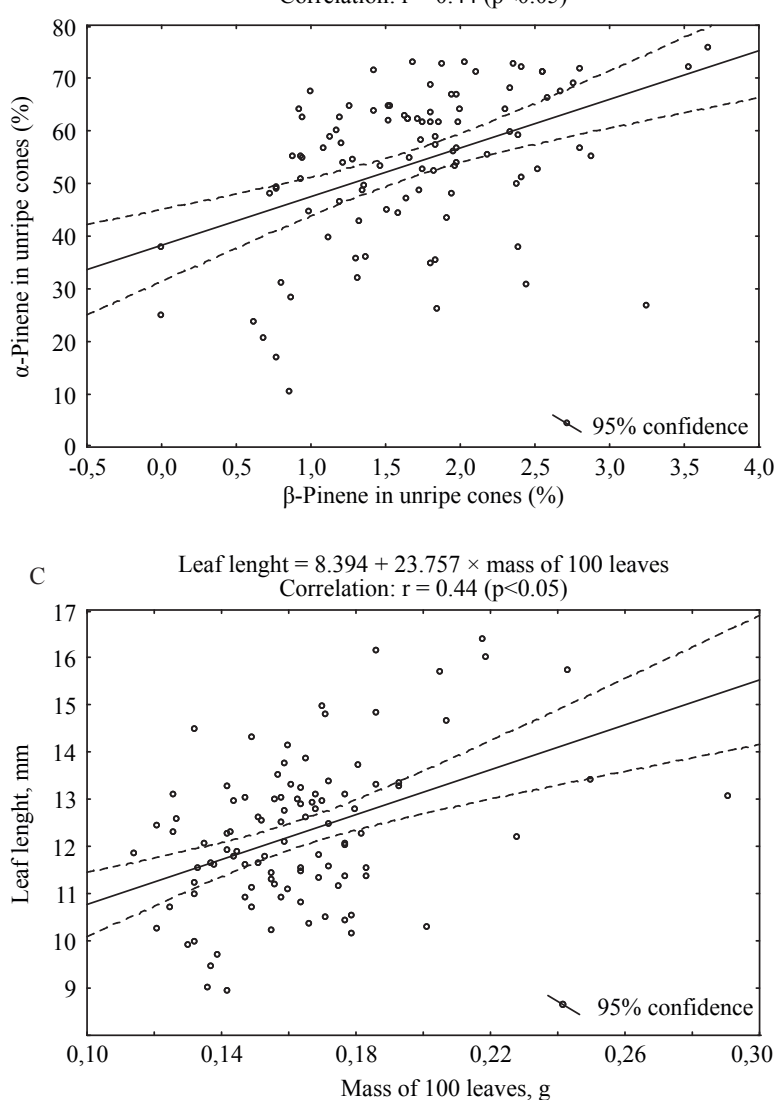

Fig. 3. Correlations between percentages of pinene isomers in leaves (A) and unripe cones (B) and between leaf length and leaf mass $(\mathrm{C})(\mathrm{n}=100$ Juniperus communis individuals)

The investigations of individual Juniperus communis shrubs $(\mathrm{n}=100)$ showed that unripe cones accumulate thrice more essential oils than leaves $(1.3 \pm$ $0.64 \%$ (SD) and $0.4 \pm 0.14 \%$ (SD), respectively). The wide ranges of values (in leaves $0.1-0.9 \%$ and in cones $0.3-4.2 \%$ ) and high coefficients of variation (in leaves 36\% and in cones 49\%) were established.

$\alpha$-Pinene was detected in leaves and cones in all investigated samples of Juniperus communis. It was the main essential oil compound in $97 \%$ of all analysed leaves and in $98 \%$ of all analysed unripe cones. The leaves and unripe cones contained very similar amounts of this monoterpene $-58.9 \pm 14.2 \%$ (SD) and $53.9 \pm 14.2 \%(\mathrm{SD})$, respectively. $\alpha$-Pinene varied within wide range, which was similar both in leaves and unripe cones: the min-max values of this monoterpene in leaves and cones were stated $11.5-76.8 \%$ and $10.4-75.8 \%$, respectively. The amounts of isomer $\beta$-pinene were less in comparison with $\alpha$-pinene: leaves contained $2.3 \pm 0.4 \%$ (SD) and cones $1.7 \pm 0.7 \%$ (SD) of $\beta$-pinene only. As distinct from $\alpha$-pinene, the cones of two J. communis shrubs absolutely did not accumulate $\beta$-pinene.

Correlation connections were observed between pinene isomers: if tree accumulated higher $\alpha$-pinene amount in cones or leaves, the higher values of $\beta$-pinene also were detected in cones or leaves of the same tree $(\mathrm{r}=0.44, \mathrm{p}<0.05$ and $\mathrm{r}=0.50, \mathrm{p}<0.05$, respectively) (Fig. 3).

The one-way analysis of variance (ANOVA) showed that the investigated 10 habitats significantly differed in leaf length, mass of 100 unripe cones, essential oil yield in leaves and $\beta$-pinene percentage in unripe cones; the highest differences between the habitats were estimated according to morphological characters (Table 2).

All investigated habitats were grouped in open habitats (No. 1-5) and shaded habitats (No. 7-11) (Table 1), because these two habitat groups differed clearly according to illumination $(\mathrm{t}=11.23, \mathrm{p}=$ $\left.4 \times 10^{-6}\right)$, soil acidity $(t=2.94, p<0.02)$, contents of mobile potassium $(\mathrm{t}=3.85, \mathrm{p}<0.005)$, organic nitrogen $(\mathrm{t}=5.54, \mathrm{p}<0.0006)$ and humus $(\mathrm{t}=4.0, \mathrm{p}<$ $0.004)$. Although the majority of chemical characters (excluding $\beta$-pinene in leaves) were higher in shaded habitats group (Table 3), these two habitat groups differed significantly according to essential oil $(\mathrm{t}=$ 3.32, $\mathrm{p}<0.001)$ and $\beta$-pinene $(\mathrm{t}=2.11, \mathrm{p}<0.04)$ yields in leaves only (Table 2). Leaf length was significantly higher in shaded habitats group $(\mathrm{t}=2.91$, $\mathrm{p}<0.004)$; while the mass of leaves and cones was higher in open habitats, however, differences were not statistically significant between open and shaded 
Table 2. One-way analysis of variance (ANOVA) of investigated 10 habitats and $t$-test comparison of two habitat groups (shaded No. 1-5 and open No. 7-11 habitats)

\begin{tabular}{|c|c|c|c|c|c|}
\hline \multirow{2}{*}{\multicolumn{2}{|c|}{$\begin{array}{l}\text { Morphological and chemical } \\
\text { characters }\end{array}$}} & \multicolumn{2}{|c|}{$\begin{array}{l}\text { One-way ANOVA testing of habitats } \\
\qquad(\mathrm{df}=9)\end{array}$} & \multicolumn{2}{|c|}{$\begin{array}{l}t \text {-testing of shaded and open habitat groups } \\
\qquad(\mathrm{df}=98)\end{array}$} \\
\hline & & $\mathrm{F}$ & $\mathrm{p}$ & $t$ & $\mathrm{p}$ \\
\hline \multicolumn{2}{|l|}{ Leaf length (mm) } & 9.25 & $8 \times 10^{-10^{*}}$ & 2.91 & $0.004^{*}$ \\
\hline \multicolumn{2}{|c|}{ Mass (g) of 100 leaves } & 1.78 & 0.08 & 1.96 & 0.05 \\
\hline \multicolumn{2}{|c|}{ Mass $(\mathrm{g})$ of 100 cones } & 4.62 & $5 \times 10^{-5 *}$ & 0.82 & 0.42 \\
\hline \multirow{2}{*}{$\begin{array}{l}\text { Essential oil yield } \\
(\%)\end{array}$} & Leaves & 3.00 & $0.004^{*}$ & 3.32 & $0.001^{*}$ \\
\hline & Unripe cones & 1.52 & 0.15 & 1.36 & 0.18 \\
\hline \multirow[t]{2}{*}{$\alpha$-Pinene $(\%)$} & Leaves & 1.71 & 0.09 & 0.65 & 0.52 \\
\hline & Unripe cones & 0.32 & 0.97 & 0.39 & 0.70 \\
\hline \multirow[t]{2}{*}{$\beta$-Pinene $(\%)$} & Leaves & 1.15 & 0.34 & 2.11 & $0.04^{*}$ \\
\hline & Unripe cones & 2.36 & $0.02^{*}$ & 1.69 & 0.09 \\
\hline
\end{tabular}

* - significant differences between habitats and habitat groups $(\mathrm{p}<0.05)$

Table 3. Descriptive characteristics of morphological and chemical characters of leaves and unripe cones of Juniperus communis in open (No. 1-5) and shaded (No. 7-11) habitats

\begin{tabular}{|c|c|c|c|c|c|c|c|}
\hline \multirow{3}{*}{\multicolumn{2}{|c|}{$\begin{array}{l}\text { Morphological and chemical } \\
\text { characters }\end{array}$}} & \multicolumn{6}{|c|}{ Habitat type } \\
\hline & & \multicolumn{3}{|c|}{ Open } & \multicolumn{3}{|c|}{ Shaded } \\
\hline & & Average \pm SD & Min & Max & Average \pm SD & Min & $\operatorname{Max}$ \\
\hline \multicolumn{2}{|l|}{ Leaf length (mm) } & $11.8 \pm 1.4$ & 8.9 & 15.7 & $12.7 \pm 1.6$ & 8.9 & 16.4 \\
\hline \multicolumn{2}{|c|}{ Mass (g) of 100 leaves } & $0.169 \pm 0.03$ & 0.114 & 0.291 & $0.158 \pm 0.03$ & 0.121 & 0.243 \\
\hline \multicolumn{2}{|c|}{ Mass (g) of 100 cones } & $2.999 \pm 0.89$ & 1.461 & 5.351 & $2.856 \pm 0.86$ & 1.730 & 5.617 \\
\hline \multirow{2}{*}{$\begin{array}{l}\text { Essential oil yield } \\
(\%)\end{array}$} & Leaves & $0.35 \pm 0.1$ & 0.11 & 0.70 & $0.44 \pm 0.1$ & 0.20 & 0.86 \\
\hline & Unripe cones & $1.23 \pm 0.5$ & 0.28 & 2.35 & $1.40 \pm 0.7$ & 0.38 & 4.15 \\
\hline \multirow{2}{*}{$\begin{array}{l}\alpha \text {-Pinene } \\
(\%)\end{array}$} & Leaves & $58.0 \pm 13.8$ & 14.1 & 76.8 & $59.9 \pm 14.6$ & 11.5 & 76.7 \\
\hline & Unripe cones & $53.4 \pm 14.5$ & 23.9 & 73.0 & $54.5 \pm 14.1$ & 10.4 & 75.8 \\
\hline \multirow{2}{*}{$\begin{array}{l}\beta \text {-Pinene } \\
(\%)\end{array}$} & Leaves & $2.3 \pm 0.4$ & 1.1 & 3.5 & $2.2 \pm 0.4$ & 0.9 & 3.0 \\
\hline & Unripe cones & $1.6 \pm 0.6$ & 0.0 & 2.7 & $1.8 \pm 0.7$ & 0.7 & 3.7 \\
\hline
\end{tabular}

habitat groups according to these two characters (Table 2 and 3 ).

Statistically significant correlations were established between habitat illumination and essential oil yield in leaves $(r=-0.67, p<0.05)$ and between soil acidity and essential oil yield in leaves $(r=-0.80, p<$ $0.05)$ only.

\section{DISCUSSION}

Cones of Juniperus communis matured in late autumn of the second year; therefore, both first-year unripe (green) cones and second-year ripe (blue or black) cones grow simultaneously on the same plant (ČIBIRas, 1959; Navasaitis et al., 2003). The unripe cones are heavier than ripe ones (SLAVĖNAS \& RAŽINSKAITÉ, 1962); also the previous study showed that unripe cones accumulate twice more essential oils than ripe cones and up to sextuple than leaves (ButKIENE et al., 2006). Our study on J. communis at individual plant level showed that unripe cones accumulate on an average thrice more essential oil than leaves, and intraspecific variation of essential oil amount is higher in unripe cones than in leaves. The reason of differences in essential oil yield in cones and leaves of $J$. communis is the structure of the secretory elements: needles, which contain ducts and transfusion tissue, act as conduction structures, and the berries containing elongate tubercles, which act as reservoirs of volatile oils (SHAHMIR et al., 2003). The intraspecific variation of the studied leaf morphological characters was also less than intraspecific variation of cones mass. Wider morphological variation of unripe cones can be related to their different ripening stage in the investigated J. communis plants. Established significant correlative connections between leaf length and leaf mass (Fig. 3) implied that 
these morphological characters of leaf can be under the influence of same genetic and/or environmental factors.

Pinene is the main volatile compound of such common coniferous genera as Picea, Pinus, Juniperus (PERSSON et al., 1996). Different biological activity is characteristic of this monoterpene, which has different applicable significance or influence on environment. For example, pinene is important constituent of Pinus sp. resins, whereof high-grade commercial solvent turpentine is producible (DAwson, 1994); accumulation of pinene in Juniperus sp. cones determines pharmacological properties of junipers (Council of Europe, 2008). Natural emission of this monoterpene from foliage of conifers is important in tropospheric chemistry, which upon oxidation has significant consequences for the ozone balance (Hallquist, 1997; AtKInson \& Arey, 2003; Williams, 2004). Two structural isomers of pinene are found in nature: $\alpha$-pinene and $\beta$-pinene. $\alpha$-Pinene is more frequent than $\beta$-pinene in plenty of conifers. For example, $\alpha$-pinene and $\beta$-pinene amounts $84.8 \pm$ $1.5 \%$ and $4.1 \pm 0.7 \%$, respectively, in Pinus sylvestris needles growing wild in Turkey (SEMIz et al., 2007), and up to $76 \%$ and $4 \%$, respectively, in resin of $P i$ nus laricio growing in south-east Corsica (CANNAC et al., 2009); analysis of the turpentine fraction from loblolly pine (Pinus taeda) stem xylem and phloem tissue, needles and roots demonstrated this material to be a complex mixture containing up to 12 different monoterpenes, with a-pinene predominating in all cases $(>65 \%)$, while $\beta$-pinene generally comprising only a small fraction of the turpentine (4-13\%) (Phillips et al., 1999). $\beta$-Pinene absent or found up to 20-60 times less than $\alpha$-pinene in different parts of many species of genus Juniperus ( $J$. excelsa in Iran, J. communis in Poland) (Осноска et al., 1997; Shanjani et al., 2010). In our study, $\alpha$-pinene was detected in leaves and cones in absolutely all investigated J. communis and not established as the main essential oil compound only in $3 \%$ and $2 \%$ of all analysed leaves and unripe cones, respectively. If unripe cones accumulated thrice more essential oil than leaves, amounts of $\alpha$-pinene were very similar in them. $J$. communis growing in Lithuania, same as other above-mentioned coniferous species, accumulate very few amounts of another pinene isomer $\beta$-pinene: to 26 times less in leaves and to 32 times less in unripe cones compared to $\alpha$-pinene. Furthermore, as distinct from $\alpha$-pinene, the cones of two $J$. communis shrubs absolutely did not synthesize $\beta$-pinene, i.e., $\alpha$-pinene is not always followed by $\beta$-pinene. The literature data suggest that there is a negative correlation between amounts of $\alpha$-pinene and 3-carene and between amounts of $\alpha$-pinene and terpinolene in Pinus sylvestris (PoHJola et al., 1989; SEMIZ et al., 2007). Such negative relationships may arise due to contrasting biochemical pathways affecting directly or indirectly each of the related compounds (MANNINEN et al., 2002). The synthesis of both pinene isomers in our investigated $J$. соттunis is interdependent: positive correlations between pinene isomers both in leaves and in cones show that $\alpha$ - and $\beta$-pinene have a common biosynthetic pathway (Fig. 3).

Morphological and chemical characters of plants are determined genetically, but many quantitative features may vary under different environmental conditions of habitats and so determine the interpopulation variation of species. Juniperus communis is the species of a global distribution exhibiting wide range of ecological adaptations (Rоoк, 2006). In Lithuania, $J$. communis occurs mostly in dry pinewoods, mixed forests, on river slopes, being light demanding, but also shade tolerant (NAvasaitis, 2004). All our investigated habitats were grouped into two groups, which significantly differed according to illumination and soil chemistry (excluding phosphorus only). One-way ANOVA and $t$-test showed significant differences between habitats and habitat groups according to leaf length and essential oil yield in leaves (Table 2), however, statistically significant correlation connections were established between essential oil yield in leaves and illumination and between essential oil yield in leaves and soil acidity only. It is known that essential oil content and composition can depend on many different environmental factors: atmospheric temperature, rainfall, light quality, soil chemistry (SANGWAn et al., 2001; Bașer \& BuCHBAuER, 2009). Negative correlation connection between essential oil yield in leaves and illumination could be explained by more intensive evaporation of volatile essential oils in sunnier than in shaded habitats. On the same score, $14 \%$ lower amount of essential oil was in cones of open habitats group, though significant correlation connection was not detected be- 

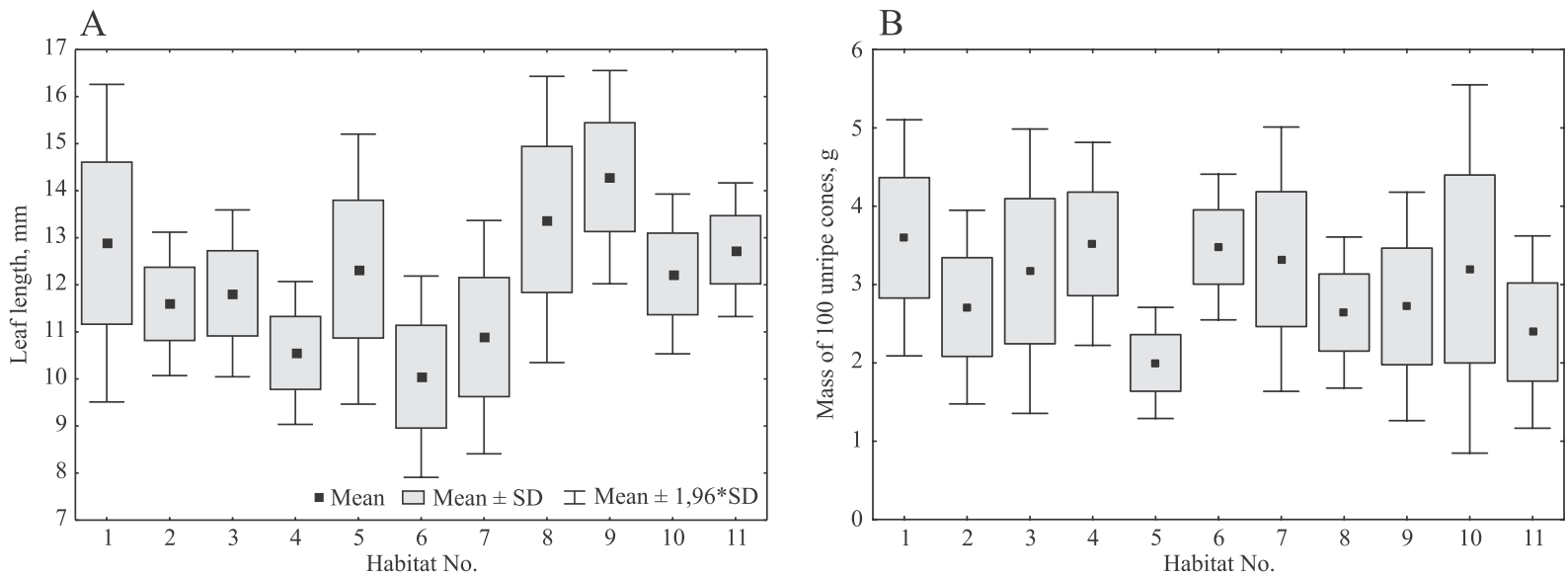

Fig. 4. Column dispersion diagrams of Juniperus communis leaf length (A) and unripe cones mass (B) in different habitats

tween essential oil yield in cones and illumination. Conifer litter caused up to $35 \%$ much higher soil $\mathrm{pH}$ in shaded habitats, which were chosen in the pinewoods, compared to the open habitats. The correlation between illumination and soil acidity was quite strong $(r=0.68, p<0.05)$. Therefore, it is difficult to judge, which of the two environmental factors influence the essential oil accumulation synergetically.

In our study, both leaf length and leaf mass of Juniperus communis varied alike at individual level and positive correlation connection was observed between these leaf morphological characters, however, habitats and habitat groups significantly differed according to leaf length only (Table 2). In many plant species it is common that leaf size adapts to the light conditions of a habitat by getting larger with decreasing light intensity; also it is indicated that the length of conifer needles is strongly related to nitrogen and phosphorus availability (CONROY et al., 1986; RAISON et al. 1992; NiINEMETS et al., 2001). In the present study, the longest leaves were produced by $J$. communis growing in shaded habitats group; also the longest leaves were established in habitat No. 9 with the least illumination. J. communis is ascribed to oligotrophs, therefore, even on an average fourfold lower amount of nitrogen in shaded habitats group did not influence leaf length. It should be noted that open control habitat No. 6 distinguished by least leaf length (Fig. 4). Although the soil of this habitat was richer (to 5 times) by organic nitrogen and humus compared to other open habitats, there trees grew under the influence of one strong natural water-stress factor: this habitat was located in a swamp, where the groundwater was at a depth of $10 \mathrm{~cm}$. The plants in high moisture amount case hardly assimilate nutrients; therefore, the abundance of moisture could have negative influence on leaf growth in this habitat.

Morphological parameters are often used for interpretation of forest status and production. One of the most widely used, and perhaps most important tests of tree quality, is the biomass and growth parameters of assimilating organs - needles (MANDRE \& OTS, 2003). The morphological characteristics are greatly influenced by carbohydrates produced in photosynthesis and by nutrients assimilated from soil and their partitioning in the organism (KLõŠEIKO, 2003; Mandre, 2003). In our study, no statistically significant difference was obtained between the investigated habitat groups according to biomasses of leaves and unripe cones, however, the mass of leaves and cones were $7 \%$ and $5 \%$ higher in open habitats, respectively. The fact that on shaded habitats, the level of photosynthetically active radiation, on which the photosynthesis of trees and the formation of organic matter in them directly depend, absorbed in the crowns of trees is somewhat lower than on the open habitats, may explain the formation of the smaller needle and cone biomass on the shaded habitats. Bigger mass of leaves and cones could also be conditioned by the higher contents of nitrogen and humus in the soil as it is proved by many studies on plant cultivation. The highest contents of nitrogen were in open habitats, where the highest contents of humus were observed as well. In shaded habitats, which occurred in pinewoods with sandy soils, where a leaching moisture regime prevails, the mobile nitrogen is leached into the deeper layers of the soil. 


\section{ACKNOWLEDGEMENTS}

This work was partly supported by the project "Promotion of Student Scientific Activities" (VP13.1-ŠMM-01-V-02-003) from the Research Council of Lithuania (Vaida Vaičiulytè). This project is funded by the Republic of Lithuania and European Social Fund under the 2007-2013 Human Resources Development Operational Programme's priority 3.

\section{REFERENCES}

Adams R.P., 1998: The leaf essential oils and chemotaxonomy of Juniperus sect. Juniperus. - Biochemical Systematics and Ecology, 26: 637-645.

Adams R.P., 2004: Junipers of the World: The Genus Juniperus. - Vancouver.

Angioni A., Barra A., Russo M.T., Coroneo V., Dessi S., Cabros P., 2003: Chemical composition of the essential oils of Juniperus from ripe and unripe berries and leaves and their antimicrobial activity. - Journal of Agriculture and Food Chemistry, 51: 3073-3078.

Atkinson R., Arey J., 2003: Atmospheric degradation of volatile organic compounds. - Chemical Reviews, 103: 4605-4638.

Bașer K.H.C., Buchbauer G., 2009: Handbook of Essential Oils: Science, Technology and Applications. - CRCPress/Taylor \& Francis.

BERTA F., 1993: Occurrence and composition of essential oils in species of the genus Juniperus. Folia Dendrologica, 20: 301-312.

Butkiente R., Nivinskienè O., Mockutė D., 2006: Differences in the Essential Oils of the Leaves (Needles), Unripe and Ripe Berries of Juniperus communis L. Growing Wild in Vilnius District (Lithuania). - Journal of Essential Oil Research, 18: 489-494.

Butkienè R., Nivinskienė O., Mockutė D., 2009: Two chemotypes of essential oils produced by the same Juniperus communis L. growing wild in Lithuania. - Chemija, 20: 195-201.

Cannac M., Barboni T., Ferrat L., Bighelli A., Castola V., Costa J., Trecul D., Morandini F., Pasqualini V., 2009: Oleoresin flow and chemical composition of Corsican pine (Pinus nigra subsp. laricio) in response to prescribed burnings. - For- est Ecology and Management, 257: 1247-1254.

Cavaleiro C., Salgueiro L.R., Figueiredo A.C.,

Barroso J.G., Bighelli A., Casanova J., 2003: Composition and variability of the essential oils of the leaves and berries from Juniperus navicularis. - Biochemical Systematics and Ecology, 31: 193-201.

Cavaleiro C., Pinto E., Goncalves M.L., SalgueiRo L., 2006: Antifungal activity of Juniperus essential oils against dermatophyte, Aspergillus and Candida strains. - Journal of Applied Microbiology, 100: 1333-1338.

Chatzopoulou P.S., Katsiotis S.T., 2003: Chemical investigation of the leaf oil of Juniperus communis L. - Journal of Essential Oil Research, 5 (6): 603-607.

Conroy J., Barlow E.W.R., Bevege D.I., 1986: Response of Pinus radiata seedlings to carbon dioxide enrichment at different levels of water and phosphorus: growth, morphology and anatomy. Annals of Botany, 57: 165-177.

Council of Europe, 2008: European Pharmacopoeia. - Strasbourg.

ČIBIRAs L., 1959: Kadagys - Juniperus L. - In: NATKeviČAité-IvanauskienĖ M. (ed.), Lietuvos TSR Flora, 1: 184-186. - Vilnius.

Dawson F.A., 1994: The amazing terpenes. - Naval Stores Review, March/April: 6-12.

Dorman H.J.D., Deans S.G., 2000: Antimicrobial agents from plants: antibacterial activity of plant volatile oils. - Journal of Applied Microbiology, 88: 308-316.

Filipowicz N., Madanecki P., Golębiowski M., StepNOWSKI P., ОсноскA J.R., 2009: HS-SPME/GC analysis reveals the population variability of terpene contents in Juniperus communis needles. Chemical Biodiversity, 6: 2290-2301.

Garcia D., Zamora R., Gomez J.M., Jordano P., HoDAR J.A., 2000: Geographical variation in seed production, predation and abortion in Juniperus communis throughout its range in Europe. - Journal of Ecology, 88: 436-446.

Gonny M., Cavaleiro C., Salgueiro L., CasanoVA J., 2006: Analysis of Juniperus communis ssp. alpina needle, berry, wood and root oils by combination of GC, GC/MS and 13C-NMR. - Flavour and Fragrance Journal, 21: 99-106.

Grubb P.J., Lee W.G., Kollmann J., Wilson J.B., 
1996: Interaction of irradiance and soil nutrient supply on growth of seedlings of ten European tall-shrub species and Fagus sylvatica. - Journal of Ecology, 84: 827-840.

Hallquist M., Wängberg I., Ljungström E., 1997: Atmospheric fate of carbonyl oxidation products originating from $\alpha$-pinene and $\Delta 3$-carene: Determination of rate of reaction with $\mathrm{OH}$ and NO3 radicals, UV absorption cross sections, and vapour pressures. - Environmental Science and Technology, 31: 3166-3172.

HUMPHREY J.W., 1996: Introduction of native ground flora species to a pine plantation in NE Scotland. Aspects of Applied Biology, 44: 9-16.

Jordan M.J., Martinez R.M., Martinez C., MonINO I., Sotomayor J.A., 2009: Polyphenolic extract and essential oil quality of Thymus zygis ssp. gracilis shrubs cultivated under different watering levels. - Industrial Crops and Products, 29: 145-153.

KLÕŠEIKO J., 2003: Relationship between the light environment and carbohydrates in needles of Scots pine (Pinus sylvestris) on a dune. - Forestry Studies/ Metsanduslikud uurimused, 39: 50-57.

Leite A.M., Lima E.O., Souza E.L., Diniz M.F.F.M., Trajano V.N., Medeiros I.A., 2007: Inhibitory effect of $\beta$-pinene, $\alpha$-pinene and eugenol on the growth of potential infections endocarditis causing Gram-positive bacteria. - Brazilian Journal of Pharmaceutical Sciences, 43: 121-125.

LožIenĖ K., Labokas J., Venskutonis P.R., MAŽDŽIERIENĖ R., 2010: Chromatographic evaluation of the composition of essential oil and $\alpha$-pinene enantiomers in Juniperus communis L. berries during ripening. - Journal of Essential Oil Research, 22: 453-458.

MANDRe M., 2003: Conditions for mineral nutrition and content of nutrients in Scots pine (Pinus sylvestris) on dunes in Southwest Estonia. - Forestry Studies, 39: 32-42.

Mandre M., Ots K., 2003: The growth of needles and shoots of Scots pine (Pinus sylvestris) on a sandy dune. - Forestry Studies, 39: 58-64.

Manninen A.M., Tarhanen S., Vuorinen M., KainuLAINEN P., 2002: Comparing the variation of needle and wood terpenoids in Scots pine provenances. - Journal of Chemical Ecology, 28: 211-228.

Marongiu B., Porcedda S., Piras A., Sanna G.,
Murreddu M., Loddo R., 2006: Extraction of $J u$ niperus communis L. ssp. nana Willd. essential oil by supercritical carbon dioxide. - Flavour and Fragrance Journal, 21: 148-154.

Navasaitis M., 2004: Lietuvos dendrologija. - Vilnius.

Navasaitis M., Ozolinčius R., Smaliukas D., BALEVIČIENĖ J., 2003: Lietuvos dendroflora. Kaunas.

Ninnemets Ü., Ellsworth D.S., LukJanova A., ToBIAS M., 2001: Site fertility and the morphological and photosynthetic acclimation of Pinus sylvestris needles to light. - Tree Physiology, 21: 1231-1244.

Ochocka J.R., Asztemborska M., Zook D.R., SybilSKA D., Perez G., Ossicini L., 1997: Enantiomers of monoterpenic hydrocarbons in essential oils from Juniperus communis. - Phytochemistry, 44: 869-873.

Persson M., Sjödin K., Borg-Karlson A.K., Norin T., Ekberg I., 1996: Relative amounts and enantiomeric compositions of monoterpene hydrocarbons in xylem and needles of Picea abies. Phytochemistry, 42: 1289-1297.

Phillips M.A., Savage T.J., Croteau R., 1999: Monoterpene Syntheses of Loblolly Pine (Pinus taeda). Produce Pinene Isomers and Enantiomers. - Archives of Biochemistry and Biophysics, 372: 197-204.

Pohjola J., Hiltunen R., Schantz M.V., 1989: Variation and inheritance of terpenes in scots pine. Flavour and Fragrance Journal, 4: 121-124.

Raison R.J., Myers B.J., Benson M.L., 1992: Dynamics of Pinus radiata foliage in relation to water and nitrogen stress. I. Needle production and properties. - Forest Ecology and Management, 52: $139-158$.

Rook E.J.S., 2006: Juniperus communis, Common Juniper - http://www.rook.org/earl/bwca/nature/shrubs/juniperuscom.html. [accessed 2204 2013].

Sangwan N.S., Faroogi A.H.A., Shabih F., SAngWAN R.S., 2001: Regulation of essential oil production in plants. - Plant Growth Regulation, 34: $3-21$.

Semiz G., Heijari J., Isik K.J., Holopainen J.K., 2007: Variation in needle terpenoids among Pinus sylvestris L. (Pinaceae) provenances from Tur- 
key. - Biochemical Systematics and Ecology, 35: 652-661.

Shahmir F., Ahmadi L., Mirza M., Korori S.A.A., 2003: Secretory elements of leafs and berries of Juniperus communis L. ssp. communis and its volatile constituents. - Flavour and Fragrance Journal, 18: 425-428.

Shanjani P.S., Mirza M., Calagari M., Adams R.P., 2010: Effects of drying and harvest season on the essential oil composition from foliage and berries of Juniperus excelsa. - Industrial Crops and Products, 32: 83-87.
Slavėnas J., RažInSKaitė D., 1962: Fitoncidinių medžiagų ir kadagio aliejaus susikaupimo Juniperus communis L. organuose dinamika. - Proceedings of the Academy of Sciences of the Lithuanian SSR, 27: 115-134.

Thomas P.A., Barghathi E.M., Polwart A., 2007: Biological Flora of the British Isles: Juniperus communis (L.). - Journal of Ecology, 95: 14041440.

WiLliams J., 2004: Organic Trace Gases in the Atmosphere: An overview. - Environmental Chemistry, 1: 125-136.

\section{PAPRASTOJO KADAGIO (JUNIPERUS COMMUNIS) LAPŲ BEI NEPRINOKUSIŲ KANKO- RËŽĖLIŲ CHEMINIŲ IR MORFOLOGINIŲ PARAMETRŲ IVAIRAVIMAS}

\section{Vaida VAIČIULYTĖ, Kristina LožIENĖ}

\section{Santrauka}

Buvo tirtas paprastojo kadagio (Juniperus communis) lapų bei neprinokusių kankorèžèlių cheminių ir morfologinių parametrų ịvairavimas tarppopuliaciniame ir individų lygiuose. Lapai ir kankorezžèliai buvo surinkti atskirai nuo 110 individų iš dešimties ekologiškai skirtingų augaviečių Lietuvoje. Eterinių aliejų analizè atlikta dujų chromatografijos metodu. Tyrimai parode, kad eterinio aliejaus daugiau susikaupia ir jų kiekis labiau įvairuoja neprinokusiuose kankorėžèliuose nei lapuose. Nustatyti dideli pineno izomerų kiekio skirtumai: lapuose ir kankorèžèliuose $\beta$-pineno buvo atitinkamai 26 ir 32 kartus mažiau nei $\alpha$-pineno. Nustatyti teigiami koreliaciniai ryšiai tarp pineno izomerų kiekio kankorěžèliuose $(\mathrm{r}=$ $0,44, p<0,05)$ ir lapuose $(r=0,50, p<0,05)$ rodo, kad egzistuoja bendras $\alpha$ - ir $\beta$-pineno biosintezès kelias. Nustatyta patikima teigiama koreliacija tarp lapų ilgio ir lapų masès $(r=0,44, p<0,05)$. Statistinè analizè parodè, kad J. communis lapų ilgiui, neprinokusių kankoréžèlių masei ir eterinio aliejaus kiekiui lapuose yra būdingi patikimai dideli tarppopuliaciniai skirtumai. Tačiau statistiškai patikimi koreliaciniai ryšiai nustatyti tik tarp eterinio aliejaus kiekio lapuose ir augavietès apšviestumo $(\mathrm{r}=-0,67$, $p<0,05)$ bei dirvožemio rūgštingumo $(r=-0,80$, $\mathrm{p}<0,05)$. 